\title{
Construction of the identity of Arabs in the novel Fatat Qarut by Sayid Abdullah Ahmad Assegaf
}

\author{
Reza Sukma Nugraha ${ }^{1}$, Eva Farhah ${ }^{2}$ and Ahmad Jazuli ${ }^{3}$ \\ $\left\{{ }^{1}\right.$ reza.sn@staff.uns.ac.id $\}$ \\ ${ }^{1}$ Arabic Department, Faculty of Cultural Sciences, Universitas Sebelas Maret
}

\begin{abstract}
This article aims to reveal the construction of the identity of Arab immigrants in the era of Dutch colonialism as represented in the novel Fatat Qarut (1929) by Sayyid Abdullah Ahmad Assegaf. The novel was written in Arabic during the colonialism era and represented the setting of Garut city. The main problem of the novel revolves around the relations of Neng, Abdullah, and Van Ridijk characters as representations of the natives (Sundanese), Arab immigrants, and Dutch colonials. The romance story among the three figures provokes some views on the identity of Arab immigrants through supporting and opposing characters. With a descriptive analytical method, this research reveals how the characters in it construct the identity of Arab immigrants from the perspective of post-colonialism. The results show that the text of Fatat Qarut confirms the identity of Arab immigrants as heroes.
\end{abstract}

Keywords: ambivalence, arabic novel, Fatat Qarut, postcolonialism

\section{Introduction}

During colonialism in the Dutch East Indies, the Arabs had a significant role in the social and political life. Same as immigrants from China and Indo-Europe, groups of immigrants from Arab even established unity organizations, such as the Indo Arabische Verbond (IAV) in 1930 [1]. The establishment of the ethnically based organization showed that the Arabs at that time had a great influence among the Indies community.

The Arab immigrants mostly came from Yemen, especially Hadramaut. This, according to Algadri (1988) is reflected in the IAV system that has adopted the Hadramaut social system. Arab-Indonesian relations also continued until Indonesia succeeded in gaining independence from the Netherlands. Arab countries, including Yemen, were one of the first countries to give recognition to Indonesia [3].

The closeness factor is also supported by many Arabic scholars who spread Islam in the Dutch East Indies. They produced many works, both religious books, Arabic learning books, and literary works. One of the important literary works of Hadramaut scholars is the novel Fatat Qarut (the Girl of Garut) written by Sayid Ahmad Abdullah Assegaf, published in 1929. Assegaf lived in Indonesia from 1908 until 1950. The novel was written in Arabic and published in Jakarta and Solo in two volumes. The first volume was published in Jakarta, while the second volume was published in Solo. 
The novel tells the story of a female character named Neng who experiences oppression done by her family and environment. It was started when her parents wished her to accept the proposal of a Dutch businessman, Van Ridjik. The story conflict focused on how Neng fought against the power of those around her, such as Rusna, Minah, Haji Mukhti, and Van Ridjik. In her efforts against these people, Neng met Abdullah, an Arab who ultimately helped her life.

As a literary work written during the colonialism era, Fatat Qarut shows many colonial issues, including the relations between the colonizers and the colonized. The reading of the novel is relevant if it is connected with post-colonialism theory. It is useful as a strategy for generating various questions that can help to identify the signs of colonialism in literary works (Day \& Foulcher, 2008, p.3). The signs of colonialism as manifested in the story, including through the characters and characterizations.

In line with this, the post-colonialism theory can be used as an analytical tool to challenge colonialism practices that are still continuing or as new colonialism [5]. The new form of colonialism creates a life filled with racism, imbalanced power, subaltern culture, hybridity, and creationism. These problems are not raised through war propaganda but are dialectized through awareness or ideas.

As a tool of analysis of literary works, post-colonialism theory criticizes the ideology of colonialism. This ideology includes the totalization, domination, and hegemony of Western culture [6]. As criticism of this ideology, post-colonialism is a new thought about cultural differences. Post-colonialism also opposes the universalism of Western cultural values, such as individualism, rationalism, functionalism, and materialism. These concepts eventually lead to the imbalance between Western and Eastern countries.

The imbalance that arises between the West and the East is the reason for the imperialism in the East. In this relation, the West positions itself as 'the Self' and regards the East as 'the Other'. This process of producing knowledge about 'the Other' is a criticsm of post-colonialism theory [7]. In other words, the post-colonialism theory criticizes Western efforts to produce 'the Other' discourse for colonized countries because the process is to perpetuate the practice of colonialization, including creating a culture of the colonized people who must be educated so that the emergence of colonial cultural hegemony.

Culture is an element of resistance. It is an ideological manifestation of the historical and physical reality of a dominating community. Therefore, in the context of colonialism, the colonialists kept trying to dominate their colonies so that the traditional culture of their colonies would be worse off and abandoned. Thus, a dynamic synthesis occurs, namely awareness to form a culture that comes from the cultural pressure of the invaders as a form of resistance. Some of the studies that contribute to this research include Suwondo (2012), which discusses exoticism, language, identity, and resistance in the Indonesian novel by Suparto Brata. From the perspective of post-colonialism, Suwondo explained the Dutch and Japanese colonialist views of the natives as an exotic, stupid, and must be fostered society. Suwondo also mentioned that the Dutch and Japanese languages as represented by Suparto Brata's novel are considered as high languages so that the natives must be able to master the language to achieve the same degree as the colonial. The issue of indigenous resistance to colonialism was also discussed by Efendi (2016). In his article, Efendi examines the resistance of characters in the short story "Samin Kembar" by Triyanto Triwikromo. The resistance of the characters in the form of mimicry, hybridity, ambivalence, diaspora, and identity in the short story. These concepts are important keywords in the study of post-colonialism. In his research, Efendi described the forms of resistance that emerged in the colonial-colonial relations.

Postcolonial reading in the two studies theoretically departed from the same problem with the text of the novel Fatat Qarut. The relation of the colonizers is an important framework that 
must be revealed in novels which tell about colonialization or the traces of colonialization. In this research, an important concept of post-colonialism that will be examined is the formation of the identity of the Arab immigrants in the Dutch East Indies in the native relations and the Dutch colonialists. The formation of this identity arises through the characters and characterizations in the novel.

Identity is a socio-cultural construction. Identity cannot exist outside of cultural representation or acculturation [10]. According to him, identity cannot be separated from subjectivity because it concerns a person. In someone, there are feelings, emotions, desires, and desires. Subjectivity also concerns one's awareness and unconsciousness. Therefore, identity is vulnerable to changes in the surrounding environment, such as the domination and hegemony of the authorities .

According to Barker, identity is divided into two, namely cultural identity and political identity. Cultural identity determines the position of the subject in relations or social interactions, while political identity determines the position of the subject in a community through a sense of belonging and at the same time marks the position of other subjects in the sense of otherness. Therefore, a subject in society can identify itself in these two kinds of identities [10]. Cultural identity is not something clear. It is a product that is never finished. It always proceeds in its formation. The formation of cultural identity occurs in a representation. The representation is an ongoing and personal process [11]. Thus, cultural identity in a person is always formed continuously in his daily life.

Hall, as explained by Erniwati (2011) states that cultural identity is related to cultural equality in a particular group of people where members have the same history and common ancestors. Therefore, in this way of thinking, cultural identity is formed through a common understanding of the history and cultural symbols of a group. Thus, the group denies other things by force so that they look like each other.

This perspective, according to Hall, is referred to as essentialist identity. Woodward (1997) explains that essentialist identity suggests that there is one clear, authentic set of characteristics which are all shared and which do not change acroscs time. This shows that essentialist identity refers to a group of people who have the same history and cultural symbols. Therefore, the arguments submitted relate to essentialist identity always give rise to binary opposition, such as the West and East, as well as the Self and Other.

The issue of identity is the main problem in the novel Fatat Qarut. In it, the relation of colonialization (native versus colonial) presents Arab immigrants as mediators between that binary relations. Arab character (Abdullah) is presented as a protagonist who is an assistant to the other main role who is a native (Neng) who tries to fight the oppression of her family and environment, including the colonialists (Van Ridijk). The identity of the Arab immigrants in the novel is interesting because culturally, the Arabs have a historical closeness to the natives (alike Islam). However, on the other hand, the Arabs are positioned as immigrants ('Vreemde Oosterlingen' Foreigners) who are politically considered superior to the natives.

\section{Research Method}

This method used in this research is descriptive analysis. The data is analyzed by content analysis technique. It is a research technique for making inferences that can be replicated and validated by paying attention to the constellation of the object used [14][15]. In this research, the content analyzed is quotations that show the construction of the identity of the Arabs. They 
were taken as data and analyzed using postcolonialism theory. The next step is to provide an interpretation of the identity construction from the viewpoint of post-colonialism. Thus, the research focuses on how the characters in the novel construct Arab identity among colonial relations.

\section{Results And Discussion}

As explained earlier, Fatat Qarut tells the story of Neng's character as a native (Sundanese) who attempts to fight his stepfather, Rusna, who wants to give her to a Dutch businessman named Van Ridijk. To pass his wish, Van Rijidk paid Rusna, Minah, and Haji Mukhti with some money. In taking the fight, Neng met with Abdullah, who helped her get out of the problem in the end.

According to the plot, the story of the novel revolves around the relations of natives such as Neng, Rusna, Minah, and Haji Mukhti with the Dutch colonialist (Van Rijidk) and Arab immigrants (Abdullah). This relation shows that the identity of the Arabs in the novel is constructed by Dutch and native colonies. The difference in construction is as follows:

\subsection{Construction of the identity of Arabs by the Dutch Colonialist}

The first identity of Arabs is constructed by the Dutch colonialists. In this case, Van Ridijk mostly talks about the character of Arabs in dialogues. One of them is seen in the following quotation:

"Beware, Rusna, if you ask for help from an Arab in our problem, including telling him what is happening between us, if he sees your daughter and hears her speak in his language, he will propose her to himself. He will scare you. Then he will argue in terms of religion. He will threaten you with tortures if you do not grant his request. If you marry him off to your daughter, then he will give up his lust and he will leave her as a burden to you and he will take another woman" [16].

The quotation is a statement from Van Ridijk to Rusna when Rusna plans to ask an Arab about Van Ridijk's proposal. However, Van Ridijk rejects Rusna's plan. He says that Arabs in the eyes of Europeans are people who are good at looking for reasons on the basis of religion and like to marry women because of lust.

The quotation shows that Van Rijidk mentions the stereotype of Arabs that prevail at that time. The stereotype is Ridijk's way of constructing Arab identity as a group of people that needs to be watched out for because they have a bad social temperament. This is marked by the pleasure of using religious reasons to smooth desires and like to get married on the basis of lust. This also appears in several other Ridijk's dialogues.

This shows the perspective of European, especially the Dutch colonialist, of representing immigrants in general [17], including Arabs. However, the social position of the Arabs at that time was above the natives. The Colonial Law of 1854 placed the Arabs as "Foreign Easterners" (Vreemde Oosterlingen). This position is the "middle class" which is located between white Europeans (Europeanen) and the lowest class of natives or local people (inlander). The position of Arabs as "Foreign Easterners" is the same as other non-European settlers, such as China and India.

The racial separation shows that the Arabs have the potential to have ambivalent attitudes between the colonizer-versus-colonized relations. On the one hand, immigrants partner well 
with the colonialist, but on the other hand, they can integrate with the natives. In addition, Arabs have an advantage over other non-European settlers because they have the same cultural identity as the majority of natives, that is, equally Muslims. In addition, the presence of Arab immigrants as "ulama" also makes them an honorable group in front of the natives.

\subsection{Construction of the identity of Arabs by Natives}

The perspective of the natives who differ from the Dutch colonialist toward the Arabs is represented by the novel through the presence of Neng as a native and several other native characters, such as Rusna and Minah. The construction of identity of Arabs by the natives can be seen in the following quotation:

When Van Ridijk spoke at length of humiliating Arabs, Neng rose after trying to contain her anger many times. But finally no longer able. She had heard their conversation that escaped her attention.

"In fact, we owe a lot to the Arabs even though others say something contrary to that ... We owe them a great deal in the development of natural sciences, useful arts, and findings that are of great benefit to Europeans in science and civilization" [16].

The quotation is a small part of the dialogue conveyed by Neng regarding Arab identity. Neng's character emerges as a pro-Arab figure because she always says that the Arabs are respectable and have many advantages. Even through Neng, the positive image of the Arabs is built through long narratives and dialogues. Dialogue, in general, is to reject the bad image of Arabs conveyed by other characters, such as Van Ridijk in the quotation above. This shows that Neng is represented as a native who sees Arabs as counter-colonial.

Such a perspective becomes natural when looking at the history of the arrival of Arabs to the Dutch East Indies. The presence of Arabs to Indonesia in addition to economic interests (trading) is also to teach the religion of Islam where Islam has been carried away in previous centuries [18]. Therefore, as second class residents, Arabs were more acceptable to pribumi. The picture is different, for example, with Chinese migrants who, according to Juningsih (2015) used to carry out social relations only for economic purposes.

The identity of the Arabs who are constructed by Neng as a hero gets resistance from the stereotypes conveyed by other natives, such as Rusna and Minah. This is reflected in the following quote:

"We really hope for the help of Haji Mukhti in this matter. We ask Haji Mukhti to try with all available capabilities to give understanding to my daughter so she wants to accept Mr. Van Ridijk. He loved her very much. But she did not seem to understand our interests. If we don't marry her with him, then she will be taken by Sundanese or Arabs. Later we will pay for them. If her husband has given her children, he will leave his children with us. We will also have to educate them later while their father leaves. It's enough what happened" [16].

The quotation tells of a dialogue between Rusna and Haji Mukhti when Rusna asks him to persuade Neng to accept Van Ridijk's proposal. Rusna assumed that the Arabs are the same as the Sundanese (natives), that is, like to leave their wives after marriage and ignore the family. This bad image supports Van Ridijk's expression of Arabs. This indicates that the text seeks to perpetuate the stereotype created by non-Arabs against Arabs. 
However, this stereotype is repeatedly opposed by Neng who acts as a native. Neng appears as a native who tries to be a helper for the Arabs who are constructed to have a bad image. Neng, as the main character, has a central role in "cleaning" the image so that the Arabs represented by Abdullah escape from the stereotype attached to them.

However, Neng's resistance becomes biased when it is later discovered that Neng is apparently of Arab descent. Neng, who is Minah's daughter, turns out to have an Arabic father (called "habib") who once had been in contact with Minah and then left her. In this position, there are two identities to be constructed. First, Arabs as imaged by Van Ridijk and Rusna are people who like to leave women after marriage. Secondly, Neng's position as a helper for the Arabs does not fully represent the native voice because historically and biologically, she is an Arab descendant.

The picture shows that the identity of the Arabs in the novel is constructed as heroes. The construction arises from Neng's resistance as a native to the negative images of Arabs that Van Ridijk said as a Dutch colonialist and Rusna as a native. The construction of the hero is based on two things. First, because the Arabs are culturally and politically close to indigenous people, especially Islam. Secondly, because ideologically, the text wants to legitimize the role of Arabs as heroes in the Dutch East Indies through the voice of Neng who is later known to be of Arab descent.

\section{Conclusion}

Based on the previous discussion it can be stated several conclusions. First, the identity of Arabs in the novel Fatat Qarut represented by the character of Abdullah is constructed in various ways from the point of view of Van Ridijk (a Dutch colonialist), Rusna (a native), and Neng (a half-Arab-native). As a colonizer and colonized, Van Ridjik-Rusna construct Arabs as a bad image. However, this bad image is countered by Neng as a representation of an Arab descendant. The resistance is an attempt to construct the identity of the Arabs as heroes. Second, the text legitimizes the identity of Arabs as heroes through the voice of Neng's character as a native who is also of Arab descent.

\section{References}

[1] H. Algadri, Politik Belanda Terhadap Islam dan Keturunan Arab. Jakarta: Masagung, 1988.

[2] K. Ali, Islam: The Key Concepts. 2007.

[3] S. A. Rahman, "Diplomasi RI di Mesir dan Negara-negara Arab pada Tahun 1947," J. Wacana, vol. 9, pp. 154-172, 2007.

[4] T. Day and K. Foulcher, "Bahasan Kolonial dalam Sastra Indonesia Modern Catatan Pendahuluan," in Sastra Indonesia Modern Kritik Poskolonial, T. Day and K. Foulcher, Eds. Jakarta: Yayasan Obor Indonesia, 2008.

[5] N. Martono, Sosiologi Perubahan Sosial Perspektif Klasik, Modern, Posmodern, dan Poskolonial. Jakarta: Raja Grafindo, 2014.

[6] S. P. Huntington, Benturan antar Peradaban. Yogyakarta: Qalam, 1992.

[7] P. William and L. Chrisman, Colonial Discourse and Postcolonial Theory: an Introduction dalam Colonial Discourse and Postcolonial Theory. New York: Harvester Wheatsheaf, 1994.

[8] T. Suwondo, "Eksotisme, Bahasa, Identitas, dan Resistensi dalam Novel Indonesia Karya Suparto Brata," J. Atavisme, vol. 15, pp. 147-162, 2012.

[9] A. N. Efendi, "Membaca Resistensi Terhadap Kolonialisme dalam Cerpen 'Samin Kembar' 
Karya Triyanto Triwikoromo," J. Pendidik. Bhs. dan Sastra, vol. 16, pp. 225-234, 2016.

[10] C. Barker, Cultural Studies, Theory and Practice. Yogyakarta: Kreasi Wacana, 2005.

[11] S. Hall, "The Questions of Cultural Identity," in Modernity and Its Futures, S. Hall, D. Held, and T. M. Grew, Eds. London: Edward Arnold, 1992.

[12] Erniwati, China Padang dalam Dinamika Masyarakat Minangkabau. Jakarta: Universitas Indonesia, 2011.

[13] K. Woordward, "Motherhood: Identities, Meaning and Myth," in Identity and Difference, London: Thousand Oaks, 1997.

[14] K. Krippendorff, Content Analysis: An Introduction to Its Metodology, 2nd ed. London: SAGE Publications, 2004.

[15] Y. M. Raharjo, S. Suwandi, and K. Saddhono, "The Values of Character Education in a novel Nun: Pada Sebuah Cermin by Afifah Afra," Hortatori J. Pendidik. Bhs. dan Sastra Indones., vol. 1, no. 2, pp. 179-186, 2017.

[16] S. A. A. Assegaf, Fatat Qarut. Jakarta: Maktabah, 1929.

[17] K. Saddhono and S. Supeni, "The role of dutch colonialism in the political life of Mataram dynasty: A case study of the manuscript of Babad Tanah Jawi," Asian Soc. Sci., vol. 10, no. 15, p. 1, 2014.

[18] N. J. G. Kaptein, Islam, Colonialism, and the Modern Age in the Netherlands East Indies: A Biography of Sayyid 'Uthman (1822-1914). Leiden: Brill, 2014.

[19] L. Juningsing, "Multikulturalisme di Yogyakarta dalam Perspektif Sejarah,” Yogyakarta, 2015. 